\title{
Upaya Peningkatan Kompetensi Dalam Membuat E-Learning Bagi Guru SMK Dinamika Kota Tegal
}

\author{
Muhammad Fikri Hidayat*1, Ginanjar Wiro Sasmito ${ }^{2}$, T. Bayu Sasongko ${ }^{3}$ \\ 1,2,3 Program Studi Teknik Informatika, Politeknik Harapan Bersama \\ e-mail: *1fikri@poltektegal.ac.id, ${ }^{2}$ anjar.dosen@gmail.com, ${ }^{3}$ theopilus.27@gmail.com
}

\begin{abstract}
Abstrak
Internet learning merupakan sebuah proses pembelajaran yang berbasis elektronik yang digunakan sebagai media pembelajaran yang dapat digunakan oleh setiap lembaga pendidikan. Dalam rangka pengembangan proses pembelajaran yang dilaksanakan di SMK Dinamika Kota Tegal, maka konsep internet learning berusaha untuk diterapkan. Metode kegiatan yang digunakan untuk mencapai tujuan dari kegiatan pengabdian masyarakat ini adalah dengan metode ceramah dan praktek dengan menggunakan media sosial Edmodo. Semua peserta pelatihan setelah mendapatkan materi yang disampaikan kemudian langsung mempraktekannya ke dalam sebuah studi kasus. Dari kegiatan pengabdian pada masyarakat ini dapat disimpulkan bahwa penerapan internet learning berbasis Edmodo yang diajarkan kepada para guru SMK Dinamika Kota Tegal mampu memberikan alternatif baru mengenai media pembelajaran berbasis teknologi informasi yang bisa digunakan dalam proses pembelajaran di kelas. Selain itu SMK Dinamika Kota Tegal selaku institusi pendidikan formal akhirnya mempunyai suatu metode pembelajaran baru yang dapat dijadikan alternatif pembelajaran.
\end{abstract}

Kata kunci-Internet Learning, Edmodo, Guru, SMK Dinamika

\section{PENDAHULUAN}

E-learning atau Internet learning adalah sebuah proses pembelajaran yang berbasis elektronik. Salah satu media yang digunakan adalah jaringan komputer. Dengan dikembangkannya di jaringan komputer memungkinkan untuk dikembangkan dalam bentuk berbasis web, sehingga kemudian dikembangkan ke jaringan komputer yang lebih luas yaitu internet. Penyajian e-learning berbasis web ini bisa menjadi lebih interaktif. Sistem e-learning ini tidak memiliki batasan akses, inilah yang memungkinkan perkuliahan bisa dilakukan lebih banyak waktu [1],[9]. E-learning digunakan sebagai istilah untuk segala teknologi yang digunakan untuk mendukung usaha-usaha pengajaran lewat teknologi elektronik internet. Oleh karena itu, istilah e-learning lebih tepat ditujukan sebagai usaha untuk membuat sebuah transformasi proses belajar mengajar yang ada di sekolah/universitas ke dalam bentuk digital yang dijembatani oleh teknologi internet [2],[10].

SMK Dinamika Kota Tegal ketika awal mula berdiri bernama STM Dinamika. Sekolah ini berdiri sejak 10 Januari 1974 di atas area tanah seluas $5600 \mathrm{~m}^{2}$ yang terletak di J1. Glatik No.68 Kota Tegal dengan status kepemilikan tanah milik Yayasan SMK Dinamika. Pendiri Yayasan SMK Dinamika Kota Tegal adalah Prof. Dr. Susnaryati, M.Si, M. Soedibjo, dan H. Syamsudin Dahlan, ST. Awal berdirinya SMK Dinamika memiliki jurusan listrik dan bangunan air, kemudian pada tahun 1980 bertambah satu jurusan baru yaitu mesin umum, kemudian tahun 1993 bertambah lagi yaitu mekanik otomotif. Pada tahun 1994 jurusan bangunan air berganti nama menjadi bangunan gedung. Kurikulum SMK Dinamika selalu berkembang mengikuti aturan yang ditetapkan oleh pemerintah dari kurikulum 1996 sampai dengan sekarang yang kurikulum 2013. 
Infrastruktur teknologi informasi yang terdapat pada SMK Dinamika Tegal sudah cukup baik, ini terbukti dari beberapa ruang kelas yang telah menggunakan LCD Proyektor, terdapat finger print untuk absensi guru dan karyawan, terdapat laboratorium komputer, laboratorium bahasa, dan perpustakaan. Beberapa guru dan karyawan pun telah memanfaatkan komputer dalam mendukung administrasi maupun pengajaran.

Namun, kegiatan belajar dan mengajar yang dilaksanakan di SMK Dinamika Tegal secara umum hanya menggunakan metode tatap muka di kelas. Padahal sarana dan prasarana yang dimiliki sudah memungkinkan untuk memanfaatkan teknologi informasi sebagai media bantu untuk mempermudah proses kegiatan belajar mengajar. Salah satu media atau aplikasi yang dapat digunakan untuk mempermudah pembelajaran adalah menggunakan Edmodo. Aplikasi ini berbasis website sehingga dapat diakses kapanpun dan dimanapun. Kelebihan lain dari aplikasi ini selain gratis adalah kemudahan penggunaannya karena tampilan user interfacenya menyerupai Facebook. E-learning merupakan sebuah media yang dapat meningkatkan mutu pendidikan [3]

Beberapa pelaksanakan kegiatan pelatihan e-learning telah dilakukan oleh tim pelaksanan kegiatan, seprti yang dilakukan oleh Somantri, Oman, dkk (2017) menerapkan media pembelajaran e-learning untuk meningkatkan kemampuan Guru dalam membuat e-learning sebagai media pembelajaran [4]. Rifiana Arief, E., (201)2 melakukan usaha peningkatan profesionalisme Guru melalui pelatihan internet dan e-learning Sekolah [5]. Amrullah, A, dkk (2012) melakukan pengembangan e-learning pada mata kuliah Komputer di program studi Teknologi Pendidikn Universitas Sriwijaya [6]. Disamping itu Wijaya, M., (2012) menerapkan sebuah pengembangan mode pembelajaran e-learning berbasis web dengan prinsip e-pedagogy dalam mningkatakan hasil belajar [7]. Nuryanti, B.L., (2009) membuat model pembelajaran e-learning melalui homepage sebagai media pembelajaran sehingga diharapkan dapat meningkatkan minat dan kreativitas siswa [8],[12].

Tujuan dari kegiatan PKM ini adalah memberikan pelatihan kepada guru SMK Dinamika Tegal untuk memanfaatkan teknologi informasi dalam melaksanakan kegiatan belajar mengajar yakni menggunakan internet learning. Kegiatan PKM yang dilaksanakan diharapkan dapat menambah pengetahuan dan pengalaman baru bagi peserta pelatihan dalam pelaksanaan metode pembelajaran, dapat memanfaatkan internet dalam proses pembelajaran serta peserta pelatihan dapat memodifikasi metode pembelajaran dengan memanfaatkan fasilitas teknologi informasi yang terdapat pada SMK Dinamika Tegal.

\section{METODE}

\subsection{Sasaran Kegiatan PKM}

Sasaran pada kegiatan pengabdian masyarakat ini yang dijadikan sebagai mitra adalah Guru SMK Dinamika Tegal mulai dari kelas 10, 11 dan 12 dari berbagai jurusan sebanyak 25 orang peserta kegiatan. Dalam pelaksanaanya kegiatan yang telah dilaksanakan terdapat beberapa faktor pendukung dan pendorong sehingga kegiatan dapat berjalan dengan lancar, diantaranya: (1) Media pelengkapan presentasi untuk pelatihan sangat memadai, sumber listrik, LCD dan pendukung lainnya juga sudah dipersiapkan dengan baik; (2) Peserta kegiatan dalam hal ini para Guru SMK Dinamika Tegal sangat antusias mengikuti kegiatan ini; (3) Dukungan pihak sekolah yang diwakili oleh Kepala SMK Dinamika memberikan motivasi tersendiri dalam menyukseskan acara pelatihan.

\subsection{Metode Kegiatan}

Metode kegiatan yang digunakan untuk mencapai tujuan dari kegiatan pengabdian masyarakat ini adalah dengan metode ceramah, diskusi dan praktek dimana pada bagian ini para peserta diberikan kesempatan untuk membuat dan mempraktekkan apa yang telah disampaikan mulai dari pembuatan account pada Edmodo sampai dengan studi kasus pembuatan tugas, quiz dan soal pilihan ganda. 


\subsection{Tahapan Kegiatan PKM}

\section{3.1 Persiapan}

Sebelum kegiatan dilaksanakan maka dilakukan persiapan-persiapan sebagai berikut: (1) Melakukan survei terhadap kebutuhan dan permasalahan yang dihadapai oleh para Guru SMK Dinamika Tegal dalam proses belajar mengajar; (2) Melakukan studi pustaka mengenai penerapan media sosial EDMODO sebagai alat bantu dalam proses belajar mengajar di kelas. (3) Melakukan persiapan perlengkapan serta peralatan sesuai kbutuhan yang diperlukan; (4) Menentukan waktu pelaksanaan dan lamanya kegiatan pengabdian bersama- sama tim pelaksana; (5) Menentukan dan mempersiapkan materi yang akan disampaikan dalam kegiatan pengabdian masyarakat.

\section{3.2 Pelaksanaan Kegiatan}

Pelaksanaan kegiatan pengabdian berlangsung pada tanggal 28 Juli 2017. Pelaksanaan kegiatan dilaksanaakan pada pukul 08.00 s.d selesai WIB dengan tempat di Lab. komputer SMK Dinamika Tegal. Materi yang disampaikan terkait dengan pemanfaatan Internet Learning yang digunakan untuk media pembelajaran Guru dalam proses belajar mengajar diantaranya adalah mengenai Pemanfaatan Edmodo dalam Membantu Kegiatan Belajar Mengajar, Pembuatan dan Pengaturan Kelas dalam Edmodo, dan Penggunaan Edmodo bagi Siswa

\section{3.3 Evaluasi Kegiatan}

Untuk mencapai target tujuan dari pelathan ini, maka pada evaluasi kegiatan peserta pelatihan diberikan tugas untuk membuat account Edmodo beserta pengaturannya sesuai dengan profile masing-masing. Hasil akhir capaian kegiatan adalah sebuah account e-learning Edmodo yang didalamnya terdapat beberapa fasilitas yang telah dibuat untuk dapt diimplementasikan pada sat proses pembelajaran di kelas.

\section{HASIL DAN PEMBAHASAN}

\subsection{Kegiatan Pelatihan}

Sebagai upaya dalam peningkatan kemampuan Guru dalam peningkatan kompetensi yaitu pada pembuatan media pembelajaran dam bentuk e-learning, pelatihan dilakukan bagi para Guru. Peserta kegiatan diberikan berbagai macam materi, diantaranya adalah sebagai berikut:

- Pemanfaatan Edmodo dalam membantu kegiatan belajar mengajar bagi guru

- Pembuatan dan Pengaturan Kelas dalam Edmodo

- Penggunaan Edmodo Bagi Siswa 


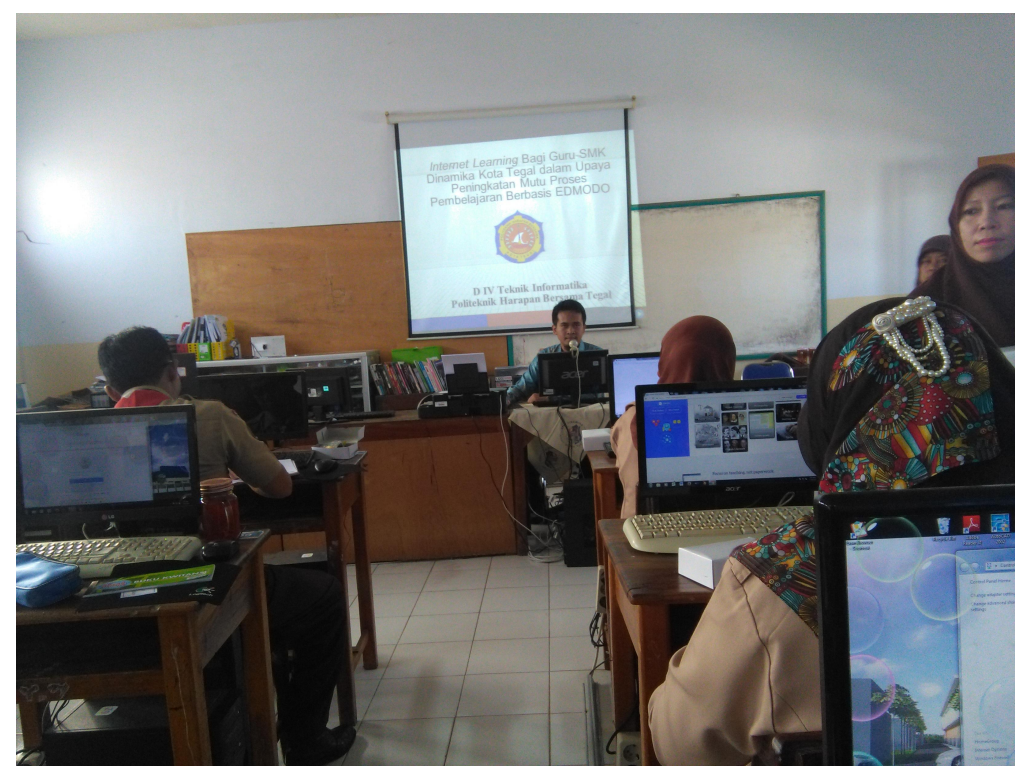

Gambar 1 Kegiatan Pengabdian di SMK Dinamika Tegal

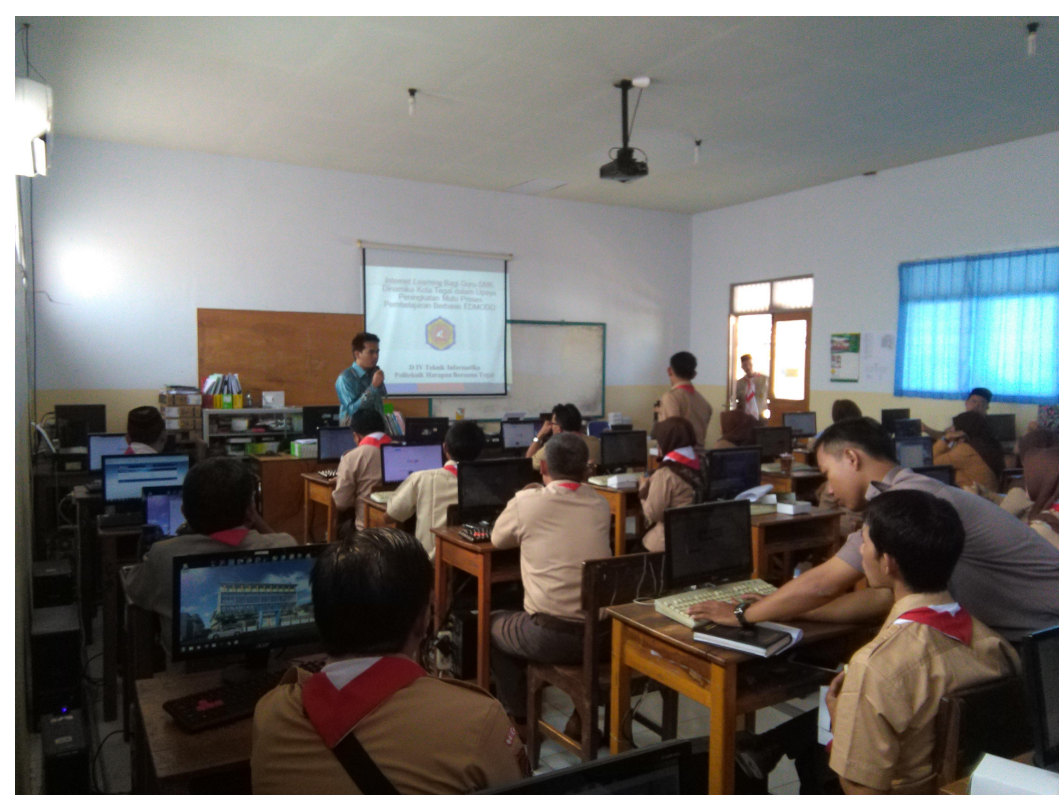

Gambar 2 Pemberian materi kepada peserta pelatihan

Pada Gambar 1 dan Gambar 2 memperlihtkan proses kegiatan pelatihan yang diikuti oleh para peserta kegiatan. Pada kegiatan ini proses pemberian materi dilakukan oleh tim pelaksana PKM yang terdiri dari Dosen dan mahasiswa sebagai tim pembantu teknik pelaksanakan PKM.

\subsection{Pendampingan Program}

Dalam pelaksanaan kegiatan pelatihan tersebut untuk memperoleh hasil luaran yang optimal maka dilakukan pendampingan baik itu pada saat proses pelaksanaan maupun pasca pelaksanaan pelatihan. Pada pelatihan ini Mahasiswa dilibatkan sebagai tim pendamping yang mendampingipeserta pelatihan agar setiap peserta dapat dengan mudah baik dalam proses pembuatan e-learning maupun konfigurasi sistem pada media pembelajaran tersebut. 


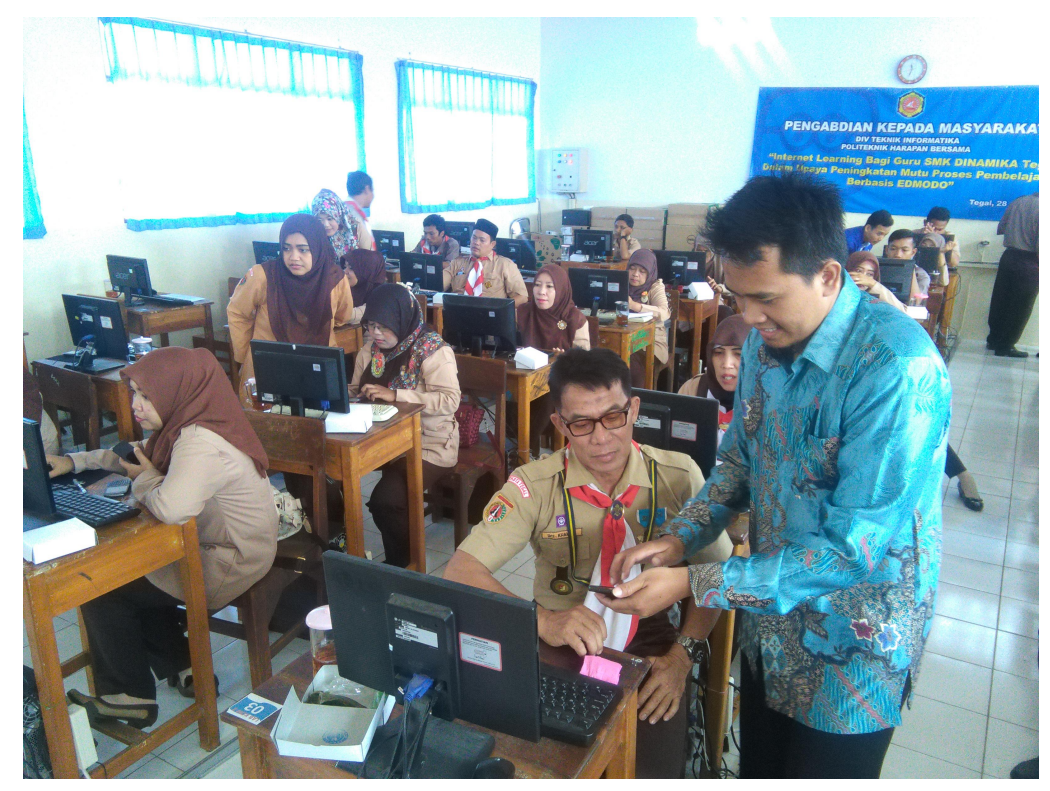

Gambar 3 Proses Pendampingan peserta kegiatan

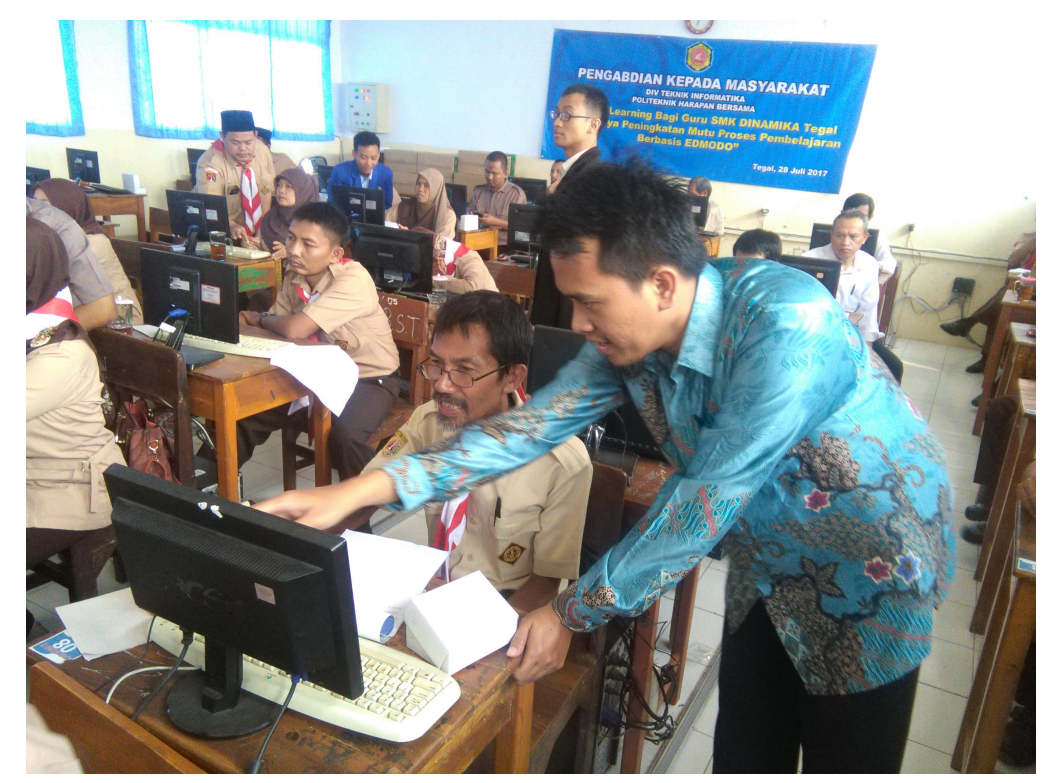

Gambar 4 Proses Pendampingan oleh mahasiswa

Pada Gambar 4 dan Gambar 5 memperlihatkan kegiatn pendampingan pada saat proses pelatihan, dimana pendampingan dilkaun oleh tim pelaksnan PKM dan Mahasiswa. Pada proses pendampingan ini peserta kegiatan diarahkan dan dibimbing langsung face-to face sehingga harapannya dapat lebih optimal dalam proses

\subsection{Capaian Kegiatan}

Kegiatan pengabdian pada masyarakat ini menghasilkan beberapa kegiatan yang dihasilkan diantaranya sebagai berikut: (1) Pemberian materi pelatihan yang diberikan kepada para Guru SMK Dinamika Tegal diterima dengan respon yang positif oleh para peserta kegiatan, disamping itu penggunaan media yang dianggap masih baru oleh para peserta memberikan daya tarik tertentu bagi para peserta sehingga banyak para peserta pelatihan yang tertarik; (2) Berdasarkan hasil praktek terhadap penggunaan internet learning ini, telah dihasilkan beberapa account baru EDMODO yang dibuat sehingga setelah kegiatan ini selesai para peserta kegiatan dapat langsung mengaplikasikannya kepada para siswa;

(3) Adanya 
ketertarikan dan keinginan dari kepala Sekolah SMK Dinamika Tegal untuk dapat mengimplementasikan hasil dari program pelatihan yang telah dilaksanakan.

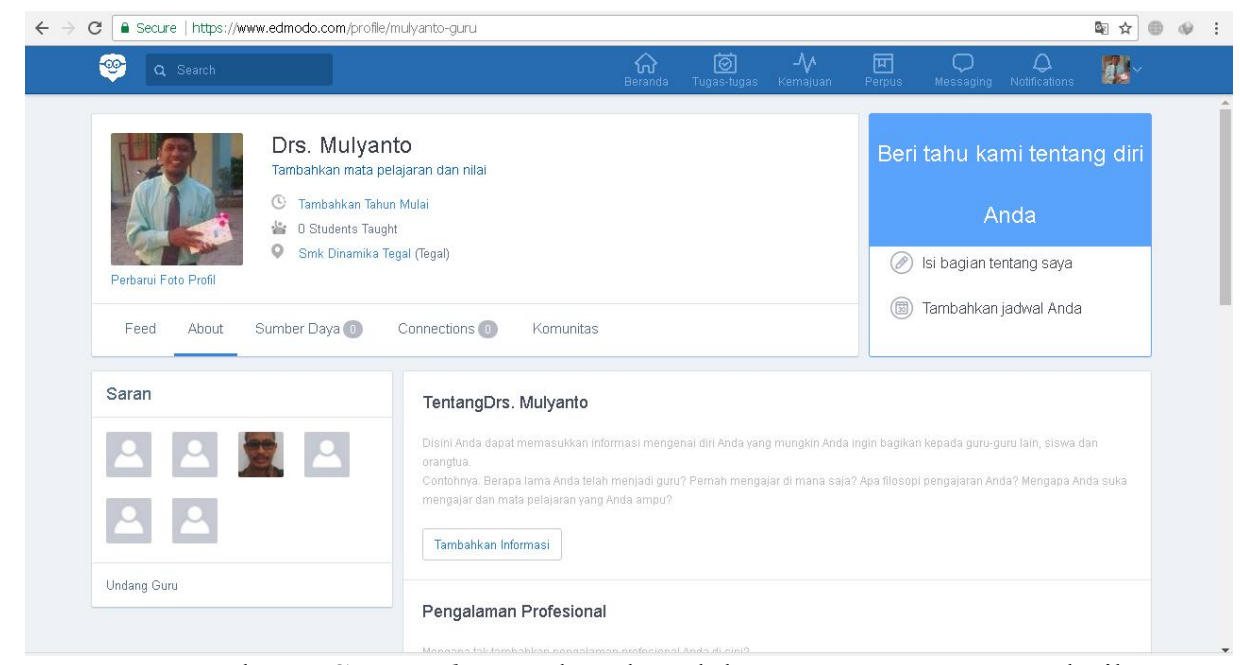

Gambar 5 Screenshoot Edmodo salah satu Guru peserta pelatihan

\section{KESIMPULAN}

Pemanfaatan teknologi informasi dalam bentuk internet learning dengan aplikasi Edmodo sebagai sarananya sangat membantu dalam proses kegiatan belajar di SMK Dinamika Tegal. Pembelajaran klasikal di dalam kelas dapat disinkronkan dengan bantuan kelas-kelas virtual untuk membantu menambahkan materi, membuat tugas dan quiz, hingga ujian semester. SMK Dinamika Tegal memiliki metode pembelajaran berbasis internet learning yang dapat dijadikan sebagai salah satu alternatif pembelajaran.

\section{SARAN}

Mengingat besarnya manfaat kegiatan pengabdian pada masyarakat ini, maka saran yang dapat dipertimbangkan diantaranya:

- Adanya pelatihan yang berkelanjutan bagi Guru SMK Dinamika Tegal sehingga dapat memperdalam kembali pengetahuan mengnai internet learning dan penerapannya.

- Perlu adanya monitoring dan evaluasi terhadap penggunaan internet learning yang sudah diberikan sehingga kita dapat mengukur sejauh mana keberhasilan dari pelatihan yang telah diberikan kepada para peserta kegiatan.

\section{UCAPAN TERIMA KASIH}

Terima kasih kepada Pusat Penelitian dan Pengabdian Masyarakat (P3M) Politeknik Hrapan Bersama Tegal yang telah membiayai kegiatan PKM yang telah dilaksanakan ini pada tahun anggaran 2017. 


\section{DAFTAR PUSTAKA}

[1] Nugroho, B., 2008. Aplikasi e-learning dengan PHP \& Editor Dreamweaver. Universitas Atma Jaya Yogyakarta, Yogyakarta.

[2] Hartanto, A. A., \& Purbo, O. W. (2002). Buku pintar internet teknologi e-learning berbasis PHP dan MySQL. Jakarta: Penerbit PT Elex Media Komputindo Kelompok Gramedia.

[3] Tafiardi, Drs. (2005). Meningkatkan mutu pendidikan melalui e-learning. Jurnal Pendidikan Penabur - No.04/ Th.IV.

[4] Somantri, O., Abidin, T., Wibowo, D.S. and Wiyono, S., 2017. Peningkatan Kemampuan Guru Dalam Membuat E-Learning Sebagai Media Pembelajaran Berbasis Teknologi Informasi Di Sma Negeri 1 Subah. Jurnal Pengabdian Kepada Masyarakat, 23(3), pp.332-337.

[5] Rifiana Arief, E., 2012. Usaha Peningkatan Profesionalisme Guru Melalui Pelatihan Internet dan E-Learning Sekolah. In Proceeding Seminar Nasional Pendidikan Teknik Elektro.

[6] Amrullah, A., Zulkardi, Z. and Hartono, H., 2012. Pengembangan E-Learning pada Mata Kuliah Komputer di Program Studi Teknologi Pendidikan Program Pascasarjanta Universitas Sriwijaya. Jurnal Inovasi Pendidikan, 2(1), pp.11-24.

[7] Wijaya, M., 2012. Pengembangan model pembelajaran e-learning berbasis web dengan prinsip e-Pedagogy dalam meningkatkan hasil belajar. Jurnal Pendidikan Penabur, 11(19), pp.20-27.

[8] Nuryanti, B.L., 2009. Model Pembelajaran E-Learning Melalui Homepage Sebagai Media Pembelajaran Sehingga Diharapkan Dapat Meningkatkan Minat Dan Kreativitas Siswa. Jurnal ABMAS (Media Komunikasi dan Informasi Pengabdian Kepada Masyarakat), 9, pp.1-7.

[9] Hartanto, A.A. and Purbo, O.W., 2002. Teknologi e-learning berbasis php dan mysq1. Elex media komputindo, Jakarta.

[10] Wahono, R.S., 2005. Pengantar e-Learning dan pengembangannya. Portal www. ilmukomputer. com Indonesia) diakses tanggal, 22.

[11] Yazdi, M., 2012, May. E-learning Sebagai Media Pembelajaran Interaktif Berbasis Teknologi Informasi. In FORISTEK: Forum Teknik Elektro dan Teknologi Informasi (Vol. 2, No. 1). 